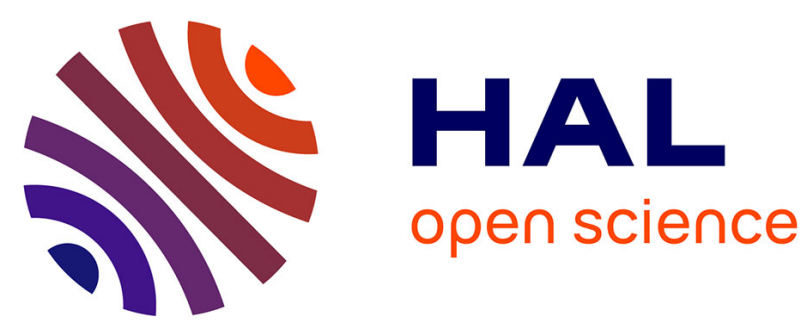

\title{
Stable isotope compositions of a late Jurassic ammonite shell: a record of seasonal surface water temperatures in the southern hemisphere?
}

\author{
C. Lécuyer, H. Bucher
}

\section{- To cite this version:}

C. Lécuyer, H. Bucher. Stable isotope compositions of a late Jurassic ammonite shell: a record of seasonal surface water temperatures in the southern hemisphere?. eEarth Discussions, 2006, 1 (1), pp.1-19. hal-00330771

\section{HAL Id: hal-00330771 \\ https://hal.science/hal-00330771}

Submitted on 15 May 2006

HAL is a multi-disciplinary open access archive for the deposit and dissemination of scientific research documents, whether they are published or not. The documents may come from teaching and research institutions in France or abroad, or from public or private research centers.
L'archive ouverte pluridisciplinaire HAL, est destinée au dépôt et à la diffusion de documents scientifiques de niveau recherche, publiés ou non, émanant des établissements d'enseignement et de recherche français ou étrangers, des laboratoires publics ou privés. 
C. Lécuyer and H. Bucher

\section{Stable isotope compositions of a late Jurassic ammonite shell: a record of seasonal surface water temperatures in the southern hemisphere?}

C. Lécuyer ${ }^{1}$ and H. Bucher ${ }^{2}$

${ }^{1}$ Laboratory "Paléoenvironnements \& Paléobiosphère", UMR CNRS 5125 , Bâtiment "Geode", Université Claude Bernard Lyon I et Institut Universitaire de France, 27-43 Boulevard du 11 Novembre 1918, 69622 Villeurbanne, France

${ }^{2}$ Paläontologisches Institut und Museum, Universität Zürich, Karl Schmid-Strasse 4, 8006 Zürich, Switzerland

Received: 15 March 2006 - Accepted: 30 March 2006 - Published: 15 May 2006

Correspondence to: C. Lécuyer (clecuyer@univ-lyon1.fr)
Jurassic seasons

$1,1-19,2006$

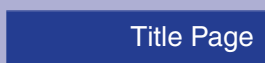

Abstract

Conclusions

References

Tables

Figures

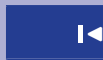

14

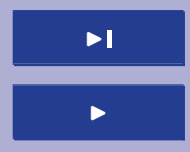

Back

Close

Full Screen / Esc

Printer-friendly Version

Interactive Discussion
Introduction 


\section{Abstract}

Exceptional preservation of aragonite secreted by ammonites offers an opportunity to determine the seasonal temperature variations of Mesozoic surface waters. Ontogenetic profiles of carbon and oxygen isotope compositions have been obtained from the 5 nacreous layer of a well-preserved Late Jurassic (Oxfordian) ammonite (Perisphinctes) from Madagascar. A similar range of oxygen isotope compositions was also obtained from an associated benthic bivalve (Astarte) which suggests the absence of sampling bias. Late Jurassic seasonal variations in the southern Hemisphere were close to $2.5^{\circ} \mathrm{C}$ and relatively weak when compared to the $2.5-6.5^{\circ} \mathrm{C}$ temperature range prevailing in the present-day Indian ocean at a paleolatitude of $40 \pm 1^{\circ} \mathrm{S}$. According to the hypothesis of an ice cap-free Late Jurassic Earth, average sea surface temperatures may have been up to $7^{\circ} \mathrm{C}$ higher than now.

\section{Introduction}

Quantification of seasonal frequency and associated thermal amplitudes as a function

of latitude contributes to define climate modes for a given geological period. This objective may be accomplished by analyzing the oxygen isotope composition of growth layers secreted by marine invertebrate shells (Epstein and Lowenstam, 1953). The end of the Jurassic is a period of long-term climate changes characterized by high seafloor spreading rates, volcanic activity, and the beginning of the global radiation of calcareous marine plankton (Frakes et al., 1992). These geological and biological processes certainly contributed to deeply modify the surface carbon cycle and consequently the Earth's climate (Tajika, 1998). The existence of ice caps has been debated (Frakes and Francis, 1988; Dromart et al., 2003) and remains fundamental to understand the budget of heat transfer and the onset of deep oceanic circulation.

Reconstitution of pre-Cretaceous climates poses a serious challenge because the fate of marine sediments is eiher to be subducted in active margins or obducted on
$1,1-19,2006$

Jurassic seasons

C. Lécuyer and H. Bucher

Title Page

Abstract

Introduction

Conclusions

References

Tables

Figures

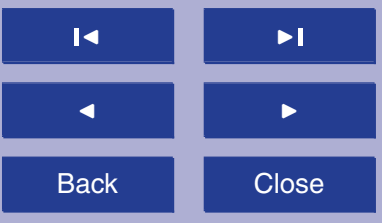

Full Screen / Esc

Printer-friendly Version

Interactive Discussion 
continents. Therefore they commonly suffered tectonic and burial processes associated with fluid-rock interactions that modified their original stable isotope composition. The exceptional preservation of aragonite secreted by nektonic ammonites provides the possibility to determine seasonal variations of sea surface temperatures (SST) for 5 the Jurassic. These data are required to improve and validate the numerical models of the Earth's climate dynamics.

An ontogenetic series of carbon and oxygen isotope compositions have been obtained from the nacreous layer of a Perisphinctes (Dichotomoceras) from the Late Jurassic (Oxfordian) series of the Morondava Basin (Maroroka section, llovo valley) 10 of southwestern Madagascar. In this area, the Late Jurassic sedimentary series consists of interfingering shallow marine and continental deposits where bathymetry did not exceed $50 \mathrm{~m}$ (Besairie, 1972). A similar ontogenetic sampling of a benthic bivalve (Astarte) from the same sediment horizon was also performed to validate the environmental interpretation of the isotopic data obtained from the ammonite. During this 15 period, this shallow marine basin was located approximately $40^{\circ} \mathrm{S}$ (Besse and Courtillot, 1988). It is shown that a periodic oxygen isotope signal may be extracted from the aragonitic shell of a Late Jurassic ammonite, thus providing the quantification of seasonal temperature amplitude for intermediate marine southern latitudes.

\section{Sampling strategy and methods}

20 A specimen of Perisphinctes was selected for its exceptional mineralogical preservation. X-ray diffraction analysis suggests that at least $99 \%$ of its nacreous layer is made of aragonite. Scanning electron microscope image of the shell at high magnification reveals a pristine aragonite ultra-structure of stacked nacreous lamellae (Buchardt and Weiner, 1981) comparable to that of the living Nautilus pompilius (Fig. 1). The examination of the ultrastructure also reveals the absence of diagenetic cement that could had precipitated in between nacreous lamellae. Radial sampling with a micro-driller of the inner nacreous layer between the primary ribs resulted in an ontogenetic sequence

Jurassic seasons

C. Lécuyer and H. Bucher

\section{Title Page}

Abstract Introduction

Conclusions References
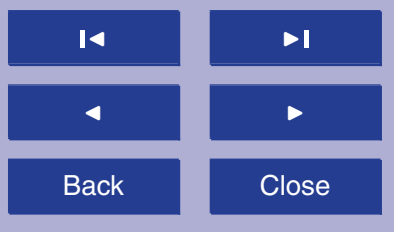

Back Close

Full Screen / Esc

Printer-friendly Version

Interactive Discussion 
of 53 samples spanning 1.7 whorls of this immature specimen (Table 1). In terms of the shell diameter, the sequence begins at $20 \mathrm{~mm}$ (sample G89) and ends at $74 \mathrm{~mm}$ (sample G1). In terms of the ventral perimeter, the sampled ontogenetic sequence amounts to $324 \mathrm{~mm}$. Exclusion of submature and mature stages from the sampled 5 sequence prevents time averaging and distorsion of the isotopic signal (Bucher et al., 1996). Careful examination of the outer shell did not reveal any breakage or growth stop that would alter the isotopic record of the environmental signal. Moreover, septal spacing observed on the polished median plane did not display any crowding as commonly generated by a prolonged pause or a temporary decrease of the apertu10 ral growth rate. For the low-Mg calcite Astarte shell, samples of the inner shell layer have been drilled at regular intervals over a linear distance of $8 \mathrm{~cm}$ from the umbo to the ventral edge (time series $A$ to $O$; Table 2), which corresponds to the maximum growth axis of the valve. Approximately $1 \mathrm{mg}$ of each powdered sample was reacted off-line with anhydrous phosphoric acid at $30^{\circ} \mathrm{C}$ over a period of $24 \mathrm{~h}$. Carbon dioxide was analyzed with a Finnigan Delta-E at the Laboratory UMR 5125 "PEPS", University Claude Bernard Lyon 1. Isotopic compositions are quoted in the standard $\delta$ notation relative to Vienna Pee Dee Belemnite (V-PDB). Carbon and oxygen isotope measurements were calibrated to the international standards NBS-18 and NBS-19. External reproducibilities for $\delta^{18} \mathrm{O}$ and $\delta^{13} \mathrm{C}$ values are $0.1 \%$ and $0.05 \%$ \% $(1 \sigma)$.

Strontium and calcium concentrations were measured by ICP-AES and ICP-MS. In the latter case, indium was used as an internal standard and the masses ${ }^{44} \mathrm{Ca}$ and ${ }^{88} \mathrm{Sr}$ were considered to avoid isobaric interferences with $\mathrm{Ar}$ compounds. Distilled $\mathrm{HNO}_{3}$ ( $\left.4.5 \mathrm{~mol}^{-\mathrm{L}^{-1}}\right)$ was used for the digestion of shell aragonite. Three international standards assessed the accuracy of measurements, which are the "Florida Phosphorite" SRM120c, the "Bone Ash" SRM1400, both from the National Institute of Standards and Technology, and the "Moroccan Phosphorite" BCR32 from the Institute for Reference Material and Measurements.

$1,1-19,2006$

Jurassic seasons

C. Lécuyer and H. Bucher

\section{Title Page}

Abstract

Introduction

Conclusion References

Tables Figures

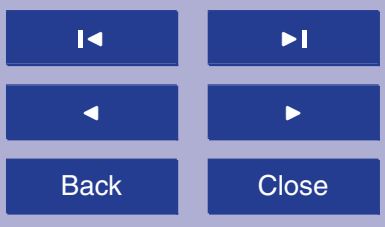

Full Screen / Esc

Printer-friendly Version

Interactive Discussion 


\section{Results}

Oxygen and carbon isotope compositions of samples G1 to G89 of Perisphinctes are given in Table 1 along with their respective position along the perimeter of the venter (arbitrary origin of the perimeter set at G89). Carbon isotope compositions vary from $5-9.7$ to $+0.7 \%$ o throughout the sampled ontogenetic series (Fig. 2). Marked fluctuations occur between $0 \mathrm{~mm}$ and $160 \mathrm{~mm}$, whereas nearly constant $\delta^{13} \mathrm{C}$ values around $0.5 \%$ occur between $160 \mathrm{~mm}$ and $325 \mathrm{~mm}$. Oxygen isotope compositions vary less than carbon, from -1.9 to $-1.1 \%$, and display successive stages of low $(\approx-1.8 \%$ ) and high $(\approx-1.2 \% \circ) \delta^{18} \mathrm{O}$ values along the sampled interval (Fig. 2). A detailed examination of these isotopic records reveals that two intervals called "isotopic events", localized from $70 \mathrm{~mm}$ to $90 \mathrm{~mm}$ and from $130 \mathrm{~mm}$ to $145 \mathrm{~mm}$, are characterized by decreases of both carbon and oxygen isotope compositions (Fig. 2). Oxygen and carbon isotope compositions of samples $\mathrm{A}$ to $\mathrm{O}$ from the Astarte are given in Table 2. Carbon isotope compositions range from +0.44 to +1.62 whereas $\delta^{18} \mathrm{O}$ values vary from -2.6 15 to $-1.8 \%$.

Molar $\mathrm{Sr} / \mathrm{Ca}$ ratios of the Perisphinctes aragonite range from $5.22 \times 10^{-3}$ to $5.39 \times 10^{-3}$ for two shell parts characterized by the relatively low and high $\delta^{18} \mathrm{O}$ values (Fig. 2).

\section{Discussion}

20 Analyzing a unique ammonite specimen questions whether its isotopic record may be representative of the local environmental conditions. Therefore, the validity of the geochemical signal of the ammonite was tested with additional measurements from an associated calcitic, benthic bivalve (Astarte). Carbon isotope compositions of the bivalve are higher than those measured in the cephalopod (Tables 1-2). A similar observation was made by Malchus and Steuber (2002) who suggested that ammonites built their shell out of equilibrium with the ambient seawater carbon.
$1,1-19,2006$

Jurassic seasons

C. Lécuyer and H. Bucher

\section{Title Page}

Abstract

Introduction

Conclusions

References

Tables

Figures
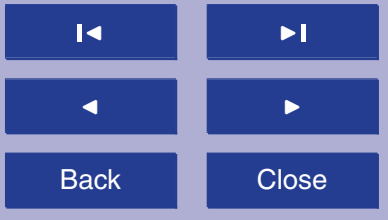

Full Screen / Esc

Printer-friendly Version

Interactive Discussion 
Despite the absence of cyclicity in the ontogenetic $\delta^{18} \mathrm{O}$ record of Astarte (Table 2), the difference between the mean $\delta^{18} \mathrm{O}$ values of Astarte and Perisphinctes remains small $(\approx 0.6 \%$ o) while internal shell variations are similar $(\approx 0.8 \%)$. This difference of $0.6 \%$ could correspond to a slight difference in the oxygen isotope fractionation be5 tween calcite-water and aragonite-water. However, the direction and amplitude of this fractionation is still poorly known. On one hand, calcite is considered to be depleted in ${ }^{18} \mathrm{O}$ relative to aragonite according to some precipitation experiments (e.g. Tarutani et al., 1969; Kim and O'Neil, 1997) and natural observations (e.g. Grossman and Ku, 1986; Barrera et al., 1994; Thorrold et al., 1997). On the other hand, theoretical calculations (Zheng, 1999) and some field observations (e.g. Horibe and Oba, 1972) suggest that calcite is ${ }^{18} \mathrm{O}$-enriched in comparison to aragonite. More recently, Lécuyer et al. (2004) did not measure any significant oxygen isotope difference between aragonitic inner and calcitic outer layers secreted by the present-day gastropod Nerita tessellata from Martinique Island. Similarly, the authors observed that calcite precipitated 15 by the oyster Crassostrea virginica has a mean $\delta^{18} \mathrm{O}$ indistinguishable from several co-existing species of aragonitic bivalves.

In any case, the measured mean $\delta^{18} \mathrm{O}$ difference between Astarte and Perisphinctes corresponds to a small temperature difference (about $2^{\circ} \mathrm{C}$ ) that can be considered as the record of natural fluctuating environmental conditions. Consequently, the oxygen 20 isotope record obtained from the Perisphinctes may be considered as reliable for estimating marine paleotemperatures. Moreover, such convergence in the respective ranges of oxygen isotope compositions suggests that both organisms dwelled in the same water mass, which is consistent with the shallow water context.

The seasonal temperature variations potentially recorded in the Perisphinctes shell 25 may be modified either by environmental perturbations or changes in the metabolic activity of the animal. The decrease in both $\delta^{13} \mathrm{C}$ and $\delta^{18} \mathrm{O}$ values, characterizing the two "isotopic events", may be interpreted as either an accidental decrease of the salinity of ambient seawater or from local diagenetic alterations of the shell. The latter case may be ruled out because X-ray diffraction analyses did not reveal re-crystallization of
$1,1-19,2006$

Jurassic seasons

C. Lécuyer and H. Bucher

Title Page

Abstract

Conclusion

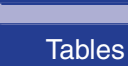

Tables

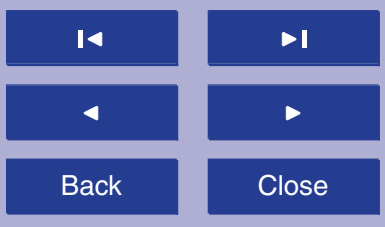

Full Screen / Esc

Printer-friendly Version

Interactive Discussion 
aragonite into calcite. Moreover, the molar $\mathrm{Sr} / \mathrm{Ca}$ ratio of the shell sample $\mathrm{G} 61$ is similar to those measured in the G1-G5 portion of the shell. $\mathrm{Sr} / \mathrm{Ca}$ ratios that range from $5.22 \times 10^{-3}$ to $5.39 \times 10^{-3}$ for the studied Perisphinctes are in good agreement with the average value of $5.53 \times 10^{-3}$ for modern aragonitic mollusks and the value of $5.78 \times 10^{-3}$ 5 for Nautilus (Milliman, 1974). Buchardt and Weiner (1981) have also analyzed numerous Upper Cretaceous specimens of Scaphites and Baculites from West Greenland. They found that $\mathrm{Sr} / \mathrm{Ca}$ ratios of aragonite shells range from $5.11 \times 10^{-3}$ to $7.23 \times 10^{-3}$ while the $\mathrm{Sr} / \mathrm{Ca}$ ratios decrease down to $2 \times 10^{-3}$ for samples totally recrystallized into calcite. These observations suggest that the Perisphinctes shell sections with low $\delta^{13} \mathrm{C}$ 10 and $\delta^{18} \mathrm{O}$ values have resulted from environmental changes that occurred during the life of the specimen. As shown by Lécuyer et al. (2004), even a limited input (about $10 \%$ ) of fresh organic-rich waters into seawater can constitute a significant source of dissolved ${ }^{12} \mathrm{C}$ during the oxidation of organic matter without significantly modifying the oxygen isotope composition of seawater. Indeed, the carbon and oxygen isotope com15 positions of modern shells living in mangroves are about $4 \%$ and $1 \%$ olower, respectively, than those living in the neighbouring open marine waters of Martinique Island. In the case study of Perisphinctes, it is noteworthy that the two "isotopic events" (Fig. 2) are characterized by a decrease of $\delta^{13} \mathrm{C}$ values that is at least five times larger than the corresponding decrease of $\delta^{18} \mathrm{O}$ values.

Excluding these two "isotopic events", the $\delta^{13} \mathrm{C}$ values increase regularly from $-9.6 \%$ o towards values close to $0 \%$ o during the first part of the studied interval (from 0 to $160 \mathrm{~mm}$; Fig. 2). Increasing $\delta^{13} \mathrm{C}$ values with age may possibly be interpreted as the result of a kinetic fractionation linked to a higher linear growth rate during the early ontogenetic stage. Such large carbon isotope fractionations have been already documented; kinetic fractionations larger than $10 \%$ o have been measured relative to the expected carbon isotope equilibrium for coral aragonite growing in local seawater (McConnaughey, 1989). Kinetic effects, however, generally also affect oxygen isotopes with a preferential incorporation of the light isotope into the carbonate, a pattern not observed in the case of our specimen (Fig. 2). Alternative explanations could be a
$1,1-19,2006$

Jurassic seasons

C. Lécuyer and H. Bucher

Title Page

Abstract

Conclusion

Tables

Figures

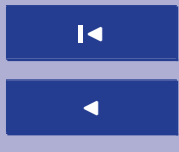

Back

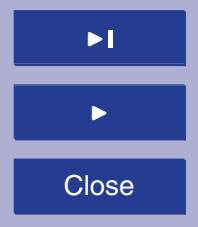

Full Screen / Esc

Printer-friendly Version

Interactive Discussion 
metabolic effect or a changing food source (Tourtelot and Rye, 1969) that will only affect carbon isotope fractionation during the growth of the animal (McConnaughey, 1989), or also a different living environment of the juvenile cephalopod where organic-rich waters represented an important source of bicarbonate ion used for the mineralization 5 of the shell. Carbon isotope compositions of the cephalopod shell could represent a quasi steady-state value of $+0.5 \%$ between $\mathrm{G} 37$ and $\mathrm{G} 1$, suggesting that stable environmental conditions prevailed during the rest of the studied ontogenetic sequence.

After removing the oxygen isotope compositions associated with the two "isotopic events", the remaining data were fit with a sine wave function (Fig. 3). The quality of this 10 fit $(r=0.79)$ suggests that the oxygen isotope compositions of the ammonite shell could correspond to the record of seasonal surface water temperature variations. Such a seasonal record is compatible with the ecology of ammonites that were nektonic instead of cephalopods such as the modern Nautilus pompilius and Nautilus macromphalus for which the isotopic patterns reflect various life stages, vertical migration and the mean 15 temperature of shell secretion below the thermocline (e.g. Cochran et al., 1981; Auclair et al., 2004). It cannot be excluded that seasonally-controlled vertical or horizontal migrations could have produced similar sinusoidal-like oxygen isotope variations recorded in the ammonite shell. However, the comparable range of $\delta^{18} \mathrm{O}$ values obtained from the Astarte shell argues in favour of the record of in situ seasonal changes. According 20 to this interpretation, the two resulting $\delta^{18} \mathrm{O}$ maxima of $-1.1 \%$ may represent the cold periods during winter seasons in the southern hemisphere (Fig. 3). If true, the seasonal amplitude is close to $0.6 \pm 0.05 \%$ and corresponds to a temperature variation of $2.5 \pm 0.2^{\circ} \mathrm{C}$ between summer and winter seasons.

Seasonal variations of the growth rate may produce asymmetric seasonal $\delta^{18} \mathrm{O}$ 25 curves for marine species that live under latitudes having contrasted and cold seasons (Cornu et al., 1993). In the case of our Perisphinctes specimen, high SST were maintained over the complete seasonal cycle and therefore precluded any cessation or slow down of the shell growth. In this seasonal frame, the two identified "isotopic events" during late winter and spring did not exceed a month and could correspond to
1, 1-19, 2006

Jurassic seasons

C. Lécuyer and H. Bucher

Title Page

Abstract

Introduction

Conclusion References

Tables Figures

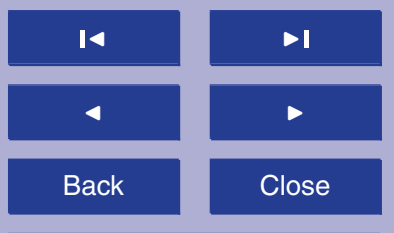

Full Screen / Esc

Printer-friendly Version

Interactive Discussion 
episodic or seasonal runoff from neighbouring hinterlands. A linear growth rate of about $0.7 \mathrm{~mm}$. day ${ }^{-1}$ is deduced from the seasonal periodic signal. This average rate is lower than that estimated from the $\delta^{18} \mathrm{O}$ signal of a Campanian Bacculites $\left(0.92 \mathrm{~mm}\right.$.day $\left.{ }^{-1}\right)$ from the Western Interior Region of North America (Fatherree et al., 1998). The growth 5 rate obtained for Perisphinctes compares with the highest available values (between 0.6 and $0.7 \mathrm{~mm}$.day ${ }^{-1}$ ) measured on Nautilus grown in a temperature-controlled aquarium (Ward, 1987).

Assuming a $\delta^{18} \mathrm{O}$ value comprised between $-1 \%$ (i.e. absence of continental ice caps) and $0 \%$ (i.e. present-day configuration) for Jurassic seawater, the calculated 10 mean annual temperature ranges from $22.5^{\circ} \mathrm{C}$ to $26.7^{\circ} \mathrm{C}$ (Fig. 3) according to the aragonite-water fractionation equation determined by Grossman and Ku (1986). These isotopic temperatures are compatible with those obtained from Late Jurassic general circulation models (e.g., Valdes et al., 1995). Late Jurassic seasonal variations in the southern Hemisphere were close to $2.5^{\circ} \mathrm{C}$ and relatively weak when compared to the

$15 \quad 2.5-6.5^{\circ} \mathrm{C}$ temperature range prevailing in the present-day Indian Ocean at a paleolatitude of $40 \pm 1^{\circ} \mathrm{S}$ (World Ocean Atlas; Levitus, 1994). For example, a seasonal oxygen isotope record has been calculated for a hypothetical aragonitic shell that grew in the temperature conditions of the present-day surface waters of the Indian Ocean at the precise latitude of $40^{\circ} \mathrm{S}-40^{\circ} \mathrm{E}$ (Fig. 3). The present-day seasonal amplitude of $3.5^{\circ} \mathrm{C}$ is $50 \%$ larger and the mean annual temperature is at least $7{ }^{\circ} \mathrm{C}$ lower than for Jurassic surface marine waters. Jurassic seasonal variations can be however slightly underestimated because the oxygen isotope composition of this nektonic ammonite does not exactly reflect sea surface temperature defined at the seawater-air interface.

\section{Conclusions}

25 Oxygen and carbon isotope compositions of aragonite sampled along the perimeter of the venter of an immature Perisphinctes specimen lead to identify a seasonal periodic signal. Two $\delta^{18} \mathrm{O}$ maxima of $-1.1 \%$ o may represent the cold periods during winter
$1,1-19,2006$

Jurassic seasons

C. Lécuyer and H. Bucher

\section{Title Page}

Abstract Introduction

Conclusions References
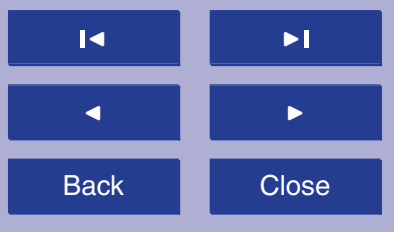

Back

Close

Full Screen / Esc

Printer-friendly Version

Interactive Discussion 
seasons in the southern hemisphere $\left(40^{\circ} \mathrm{S}\right)$. The seasonal amplitude appears to be close to $0.6 \pm 0.05 \%$ o and corresponds to a temperature variation of $2.5 \pm 0.2^{\circ} \mathrm{C}$ between summer and winter seasons. This seasonal record allows calculating a shell growth rate of about $0.7 \mathrm{~mm}$.day ${ }^{-1}$. Assuming a $\delta^{18} \mathrm{O}$ value of ambient seawater comprised 5 between $-1 \%$ and $0 \%$, mean annual temperatures higher than $20^{\circ} \mathrm{C}$, associated with a low seasonal amplitude, are most likely indicative of tropical climatic conditions at $40^{\circ} \mathrm{S}$ during the Late Jurassic.

\section{References}

Auclair, A.-C., Lécuyer, C., Bucher, H., and Sheppard, S. M. F.: Carbon and oxygen isotope composition of Nautilus macromphalus: a record of thermocline waters off New Caledonia, Chem. Geol., 207, 91-100, 2004.

Barrera, E., Tevesz, M. J. S., Carter, J. G., and McCall, P. L.: Oxygen and carbon isotopic composition and shell microstructure of the bivalve Latermula elliptica from Antarctica, Palaios, 9, 275-287, 1994.

Besairie, H.: Géologie de Madagascar. I. Les terrains sédimentaires, Ann. Géol. Madagascar, $35 \mathrm{p}, 1972$.

Besse, J. and Courtillot, V.: Paleogeographic maps of the continents bordering the Indian Ocean since the Early Jurassic, J. Geophys. Res., 93, 11719-11808, 1988.

Buchardt, B. and Weiner, S.: Diagenesis of aragonite from Upper Cretaceous ammonites: a geochemical case study, Sedimentology, 28, 423-438, 1981.

Bucher, H., Landman, N. H., Klofak, S. M., and Guex, J.: Mode and rate of growth in ammonoids, in: Ammonoid Paleobiology, edited by: Landman, N. H., Tanabe, K., and Davis, R. A., Topics in Geobiology, 408-453, Plenum Press, New York, 1996.

Cochran, J. K, Rye, D. M., and Landman, N. H.: Growth rate and habitat of Nautilus pompilius inferred from radioactive and stable isotope studies, Paleobiol., 7, 469-480, 1981.

Cornu, S., Pätzold, J., Bard, E., Meco, J., and Cuerda-Barcelo, J.: Paleotemperature of the last interglacial period based on $\delta^{18} \mathrm{O}$ of Strombus bubonius from the western Mediterranean Sea, Palaeogeogr. Palaeoclimatol. Palaeoecol., 103, 1-20, 1993.
$1,1-19,2006$

Jurassic seasons

C. Lécuyer and H. Bucher

\section{Title Page}

Abstract

Introduction

Conclusions

References

Tables

Figures
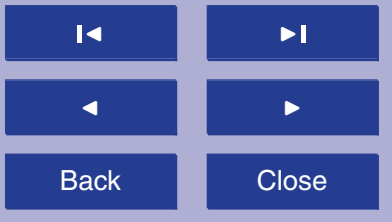

Back

Close

Full Screen / Esc

Printer-friendly Version

Interactive Discussion 
Dromart, G., Garcia, J.-P., Picard, S., Atrops, F., Lécuyer, C., and Sheppard, S. M. F.: Ice age at the Middle-Late Jurassic transition?, Earth Planet. Sci. Lett., 213, 205-220, 2003.

Epstein, S. and Lowenstam, H. A.: Temperature-shell-growth relations of recent and interglacial Pleistocene shoal-water biota from Bermuda, J. Geol., 61, 424-438, 1953.

5 Fatherree, J. W., Harries, P. J., and Quinn, T. M.: Oxygen and carbon isotopic "dissection" of Baculites compressus (Mollusca: Cephalopoda) from the Pierre Shale (Upper Campanian) of South Dakota: implications for paleoenvironmental reconstructions, Palaios, 13, 376-385, 1998.

Frakes, L. A. and Francis, J. E.: A guide to Phanerozoic cold polar climates from high-latitude ice-rafting in the Cretaceous, Nature, 333, 547-549, 1988.

Frakes, L. A., Francis, J. E., and Syktus, J. I.: Climates Modes of the Phanerozoic, Cambridge University Press, Cambridge, 1992.

Grossman, E. L. and Ku, T.-L.: Oxygen and carbon isotope fractionation in biogenic aragonite: temperature effects, Chem. Geol., 59, 59-74, 1986.

15 Horibe, S. and Oba, T.: Temperature scales of aragonite-water and calcite-water systems, Fossils, 23/24, 69-79, 1972.

Kim, S. T. and O'Neil, J. R.: Equilibrium and nonequilibrium oxygen isotope effects in synthetic carbonates, Geochim. Cosmochim. Acta, 61, 3461-3475, 1997.

Lécuyer, C., Reynard, B., and Martineau, F.: Stable isotope fractionation between mollusc 20 shells and marine waters from Martinique Island, Chem. Geol., 213, 293-305, 2004.

Levitus 94: World Ocean Atlas, an atlas of objectively analyzed fields of major ocean parameters, http://ingrid.Ideo.columbia.edu/SOURCES/.LEVITUS94/, 1994.

Malchus, N. and Steuber, T.: Stable isotope records $(\mathrm{O}, \mathrm{C})$ of Jurassic aragonitic shells from England and NW Poland: palaeoecologic and environmental implications, Geobios, 35, 2939, 2002.

McConnaughey, T.: ${ }^{13} \mathrm{C}$ and ${ }^{18} \mathrm{O}$ isotopic disequilibrium in biological carbonates: I. Patterns, Geochim. Cosmochim. Acta, 53, 151-162, 1989.

Milliman, J. D.: Marine Carbonates. Part I. Recent Sedimentary Carbonates, Springer Verlag, Berlin, 375 p, 1974.

30 Tajika, E.: Climate change during the last 150 million years: reconstruction from a carbon cycle model, Earth Planet. Sci. Lett., 160, 695-707, 1998.

Tarutani, T., Clayton, R. N., and Mayeda, T. K.: The effect of polymorphism and magnesium substitution on oxygen isotope fractionation between calcium carbonate and water, Geochim. 
Cosmochim. Acta, 33, 987-996, 1969.

Thorrold, S. R., Campana, S. E., Jones, C. M., and Swart, P. K.: Factors determining $\delta^{13} \mathrm{C}$ and $\delta{ }^{18} \mathrm{O}$ fractionation in aragonitic otoliths of marine fish, Geochim. Cosmochim. Acta, 61, 2909-2919, 1997.

5 Tourtelot, H. A. and Rye, R. O.: Distribution of oxygen and carbon isotopes in fossils of late Cretaceous age, western interior region of north America, Geol. Soc. Am. Bull., 80, 19031922, 1969.

Valdes, P. J., Sellwood, B. W., and Price, G. D.: Modelling Late Jurassic Milankovitch climate variations, in: Orbital Forcing, edited by: House, M. R. and Gale, A. S., Timescales and Cyclostratigraphy, 115-132, Geol. Soc. Spec. Pub., 1995.

Ward, P. D.: The Natural History of Nautilus, Allen \& Unwin, Boston, 1987.

Zheng, Y.-F.: Oxygen isotope fractionation in carbonate and sulfate minerals, Geochem. J., 33, 109-126, 1999.
$1,1-19,2006$

\section{Jurassic seasons}

C. Lécuyer and H. Bucher

\section{Title Page}

Abstract

Introduction

Conclusion

References

Tables

Figures
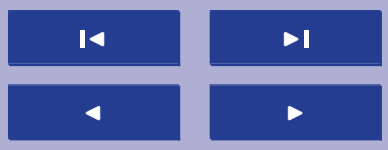

Back

Close

Full Screen / Esc

Printer-friendly Version

Interactive Discussion 
Table 1. Oxygen and carbon isotope compositions of external shell increments of an Oxfordian ammonoid Perisphinctes sp. from Madagascar. The start of the measured ontogenetic sequence is arbitrarily set at zero ventral length.

\begin{tabular}{rrrr}
\hline Sample & $\begin{array}{r}\delta^{13} \mathrm{C} \\
(\% \circ) \\
(\text { PD) }\end{array}$ & $\begin{array}{r}\delta^{18} \mathrm{O} \\
(\mathrm{PDB})\end{array}$ & $\begin{array}{r}\text { ventral } \\
\text { length } \\
(\mathrm{mm})\end{array}$ \\
\hline G1 & 0.67 & -1.25 & 325.0 \\
G2 & 0.59 & -1.29 & 321.2 \\
G3 & 0.23 & -1.37 & 314.0 \\
G4 & 0.28 & -1.26 & 307.0 \\
G5 & 0.47 & -1.11 & 302.5 \\
G6 & 0.04 & -1.32 & 298.0 \\
G7 & 0.44 & -1.12 & 294.0 \\
G8 & 0.60 & -1.31 & 289.4 \\
G9 & 0.29 & -1.21 & 285.5 \\
G10 & 0.37 & -1.35 & 280.8 \\
G11 & 0.35 & -1.28 & 277.6 \\
G12 & 0.29 & -1.55 & 273.1 \\
G13 & 0.38 & -1.25 & 268.0 \\
G14 & 0.51 & -1.33 & 263.0 \\
G15 & 0.45 & -1.32 & 258.5 \\
G16 & 0.56 & -1.34 & 253.4 \\
G17 & 0.36 & -1.58 & 248.8 \\
G19 & 0.18 & -1.85 & 240.0 \\
G21 & 0.14 & -1.81 & 230.8 \\
G23 & 0.23 & -1.69 & 222.5 \\
G25 & 0.18 & -1.71 & 213.5 \\
G27 & 0.25 & -1.80 & 204.5 \\
G29 & 0.20 & -1.70 & 196.3 \\
G31 & -0.13 & -1.74 & 188.4 \\
G33 & 0.35 & -1.77 & 180.2 \\
G35 & 0.30 & -1.61 & 172.5 \\
G37 & 0.43 & -1.47 & 163.0 \\
G39 & 0.38 & -1.62 & 156.0 \\
\hline & & & \\
\hline & & & \\
\hline
\end{tabular}

1, 1-19, 2006

\section{Jurassic seasons}

C. Lécuyer and H. Bucher

\section{Title Page}

\begin{tabular}{|c|c|}
\hline Abstract & Introduction \\
\hline Conclusions & References \\
\hline Tables & Figures \\
\hline
\end{tabular}

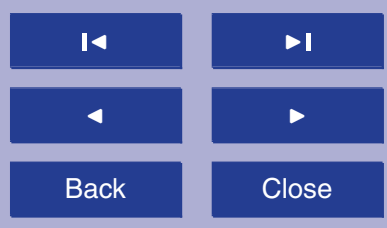

Full Screen / Esc

Printer-friendly Version

Interactive Discussion 
Table 1. Continued.

1, 1-19, 2006

\begin{tabular}{rrrr}
\hline Sample & $\begin{array}{r}\delta^{13} \mathrm{C} \\
(\%) \\
(\mathrm{PDB})\end{array}$ & $\begin{array}{r}\delta^{18} \mathrm{O} \\
(\mathrm{PDB})\end{array}$ & $\begin{array}{r}\text { ventral } \\
\text { length } \\
(\mathrm{mm})\end{array}$ \\
\hline G41 & 0.02 & -1.68 & 148.0 \\
G43 & -2.85 & -1.67 & 140.6 \\
G45 & -1.50 & -1.69 & 133.0 \\
G47 & 0.05 & -1.24 & 125.7 \\
G49 & 0.02 & -1.14 & 118.3 \\
G51 & 0.00 & -1.07 & 108.7 \\
G53 & 0.02 & -1.24 & 101.0 \\
G55 & -0.44 & -1.28 & 94.6 \\
G57 & -7.02 & -1.65 & 87.3 \\
G59 & -6.39 & -1.83 & 81.0 \\
G61 & -6.83 & -1.59 & 74.6 \\
G63 & -5.82 & -1.94 & 68.5 \\
G65 & -2.76 & -1.36 & 61.6 \\
G67 & -3.49 & -1.18 & 55.6 \\
G69 & -2.89 & -1.28 & 50.2 \\
G71 & -2.66 & -1.38 & 44.4 \\
G73 & -1.96 & -1.27 & 38.6 \\
G75 & -4.91 & -1.42 & 33.0 \\
G77 & -2.33 & -1.24 & 27.6 \\
G79 & -1.95 & -1.40 & 22.2 \\
G81 & -5.88 & -1.39 & 17.6 \\
G83 & -7.13 & -1.14 & 13.0 \\
G85 & -9.67 & -1.32 & 8.4 \\
G87 & -6.52 & -1.11 & 3.8 \\
G89 & -9.62 & -1.41 & 0.0 \\
\hline & & &
\end{tabular}

\section{Jurassic seasons}

C. Lécuyer and H. Bucher

Title Page

\begin{tabular}{|c|c|}
\hline Abstract & Introduction \\
\hline Conclusions & References \\
\hline Tables & Figures \\
\hline I4 & \multicolumn{1}{|c|}{$\mid$} \\
\hline 4 & $\bullet$ \\
\hline Back & Close \\
\hline Full Screen / Esc \\
\hline Printer-friendly Version \\
\hline Interactive Discussion
\end{tabular}


Table 2. Ontogenetic record of carbon and oxygen isotope compositions of Astarte sp. indet. This bivalve comes from the same horizon than Perisphinctes. Samples have been drilled from the intermediate shell layer at regular intervals over a linear distance of $8 \mathrm{~cm}$, which corresponds to the maximum growth axis of the valve. Aging from samples $A$ to $\mathrm{O}$.

\begin{tabular}{lll}
\hline Sample & $\begin{array}{l}\delta^{13} \mathrm{C} \% \circ \\
(\mathrm{PDB})\end{array}$ & $\begin{array}{l}\delta^{18} \mathrm{O} \% \\
(\mathrm{PDB})\end{array}$ \\
\hline Ast-A & 1.18 & -1.91 \\
Ast-B & 0.44 & -1.79 \\
Ast-C & 0.93 & -2.57 \\
Ast-D & 1.01 & -1.95 \\
Ast-E & 1.49 & -2.11 \\
Ast-F & 1.26 & -2.11 \\
Ast-G & 1.06 & -2.39 \\
Ast-H & 1.33 & -2.04 \\
Ast-I & 1.07 & -2.04 \\
Ast-J & 0.96 & -1.83 \\
Ast-K & 0.97 & -2.11 \\
Ast-L & 1.46 & -1.89 \\
Ast-M & 1.28 & -2.11 \\
Ast-N & 1.34 & -2.12 \\
Ast-O & 1.62 & -2.19 \\
& & \\
Mean & 1.16 & -2.08 \\
Std dev $(1 \sigma)$ & 0.29 & 0.21 \\
\hline
\end{tabular}

1, 1-19, 2006

\section{Jurassic seasons}

C. Lécuyer and H. Bucher

\section{Title Page}

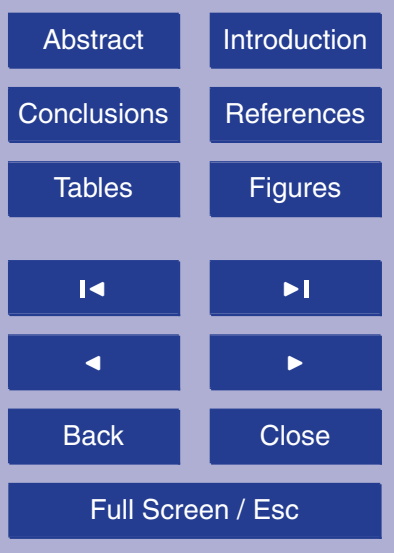

Printer-friendly Version

Interactive Discussion 


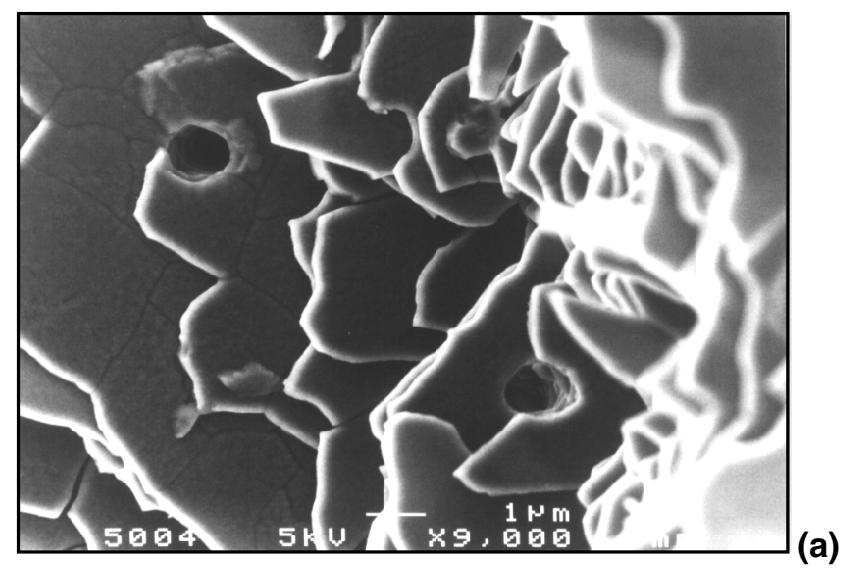

$1,1-19,2006$

\section{Jurassic seasons}

C. Lécuyer and H. Bucher

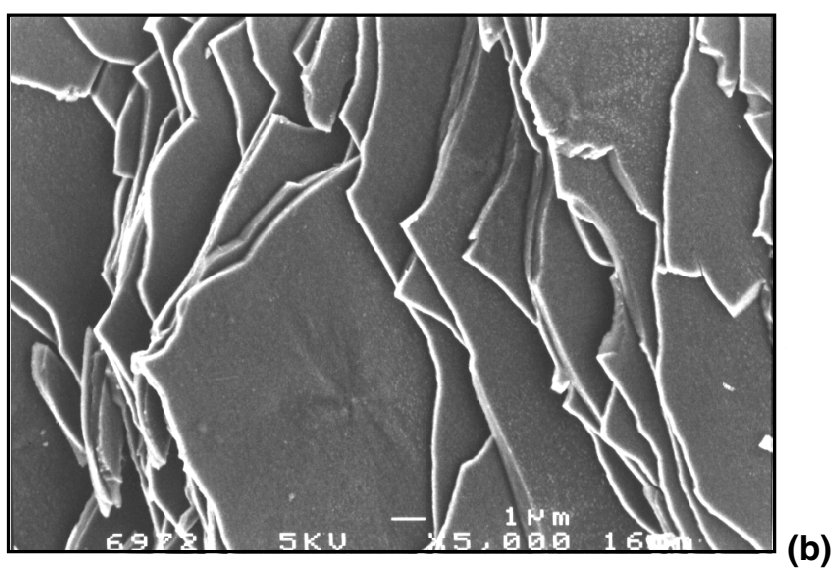

Title Page

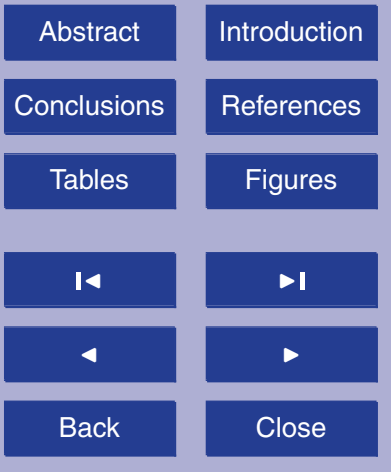

Full Screen / Esc

Printer-friendly Version

Interactive Discussion

Fig. 1. Scanning electron microscope (SEM) image of the nacreous layer of a Nautilus pompilius $(5000 \times)$. At a higher magnification $(9000 \times)$, the external shell structure of the studied Oxfordian Perisphinctes sp. displays a similar pristine stacking of nacreous lamellae without dissolution features or re-crystallization into calcite. The two holes may have been formed by symbiotic micro-algae. 


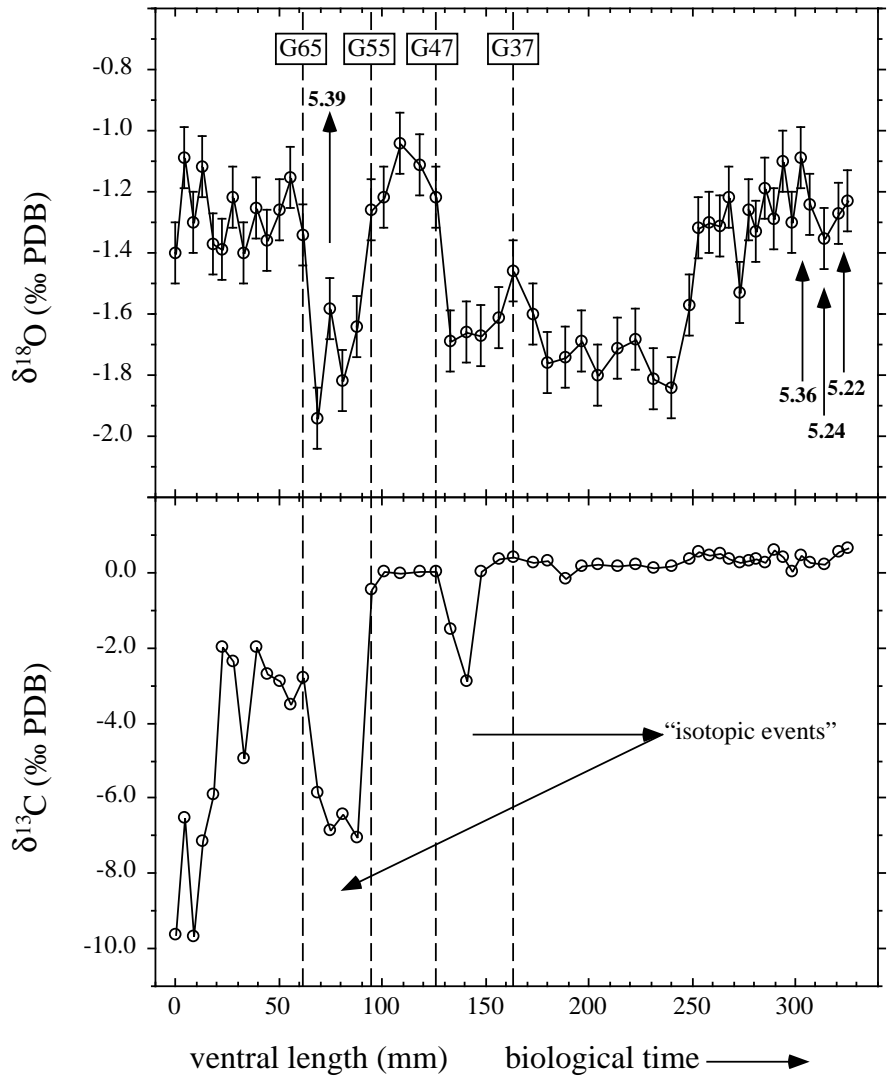

Fig. 2. Variations in the $\delta^{18} \mathrm{O}$ and $\delta^{13} \mathrm{C}$ values of aragonite as a function of the ventral length of an Oxfordian Perisphinctes from Madagascar. Two zones of the shell are characterized by associated decreases in both $\delta^{18} \mathrm{O}$ and $\delta^{13} \mathrm{C}$ values down to $-1.7 \%$ ond $-2.9 \%$ from $\mathrm{G} 37$ to G47, and down to $-1.9 \%$ and $-7 \%$ from G55 to G65, respectively. Numbers in bold refer to molar $\mathrm{Sr} / \mathrm{Ca}$ ratios.
$1,1-19,2006$

\section{Jurassic seasons}

C. Lécuyer and H. Bucher

\section{Title Page}

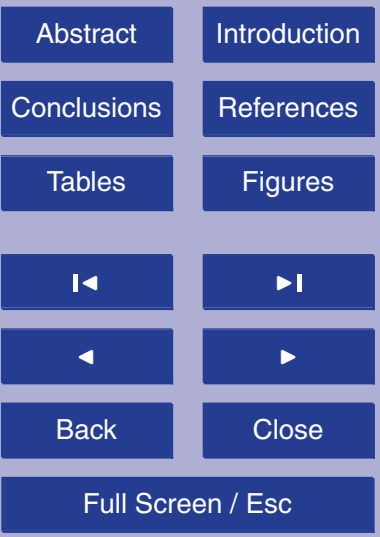

Printer-friendly Version

Interactive Discussion 


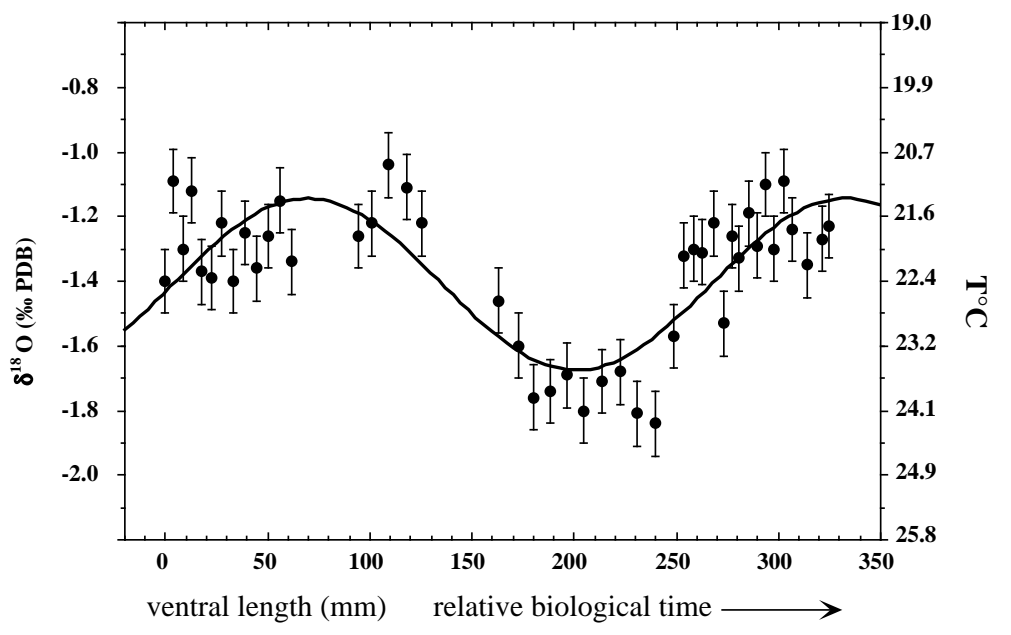

1, 1-19, 2006

\section{Jurassic seasons}

C. Lécuyer and H. Bucher

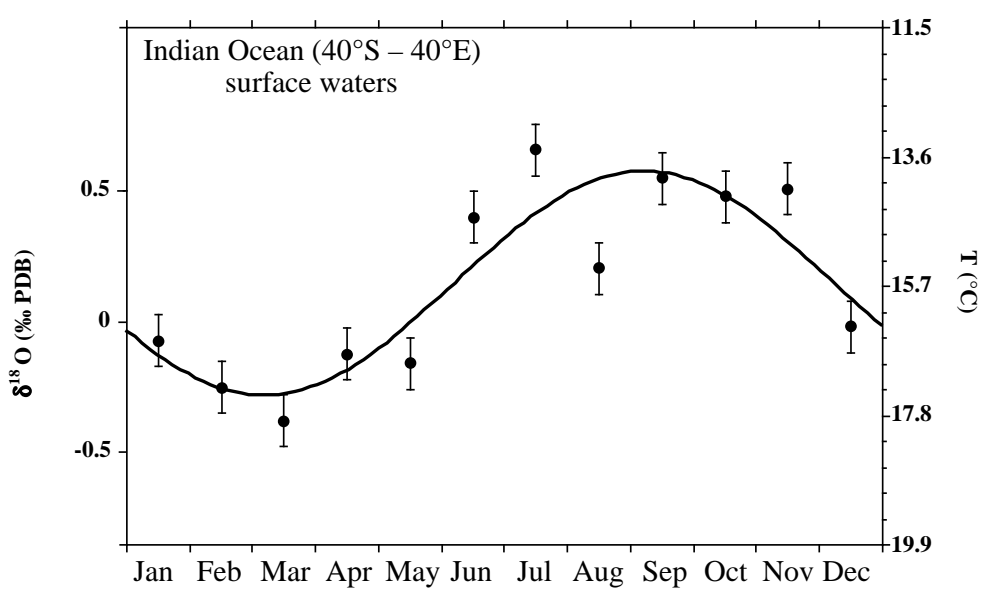

Title Page

\begin{tabular}{|c|c|}
\hline Abstract & Introduction \\
\hline Conclusions & References \\
\hline Tables & Figures \\
\hline
\end{tabular}

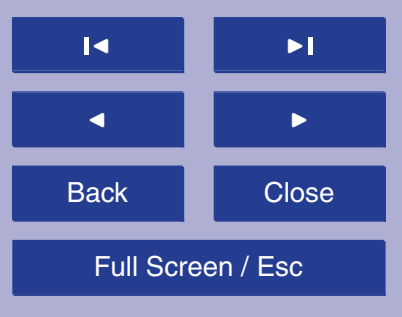

Printer-friendly Version

Interactive Discussion

Fig. 3. 


\section{Jurassic seasons}

C. Lécuyer and H. Bucher

Fig. 3. (a) Seasonal oxygen isotope variations recorded in the external shell growth layers of the Oxfordian ammonite Perisphinctes sp. The data have been fitted by least square approximations $(r=0.79)$ with a sine wave function $\left.\left(y=\left[m 1^{*} \sin \left(\left(m 2^{*} m 0\right)+m 4\right)\right)+m 3\right]\right)$ after removal of the two "isotopic events" interpreted as resulting from an input of organic-rich fresh waters. Marine temperatures, that have been reported on the right vertical axis of the diagram, have been calculated using the fractionation equation of Grossman and Ku (1986) for biogenic aragonite and assuming that the ambient seawater had a constant $\delta^{18} \mathrm{O}$ value of $-1 \%$ (hypothesis of an ice cap-free world). (b) Seasonal $\delta^{18} \mathrm{O}$ variations of biogenic aragonite calculated with the present-day surface water temperatures of the western Indian Ocean at $40^{\circ} \mathrm{S}-40^{\circ} \mathrm{E}$. Seawater temperature values come from the World Ocean Atlas (Levitus, 1994). This latitude is supposed to be closely that of Madagascar during the Oxfordian. The isotopic values have been calculated using the fractionation for biogenic aragonite (Grossman and Ku, 1986) and fitted by least square approximations $(r=0.88)$ with a sine wave function. The $\delta^{18} \mathrm{O}$ value of seawater was set to $-1 \%$ in order to compare with the Perisphinctes oxygen isotope record shown in Fig. 3a.

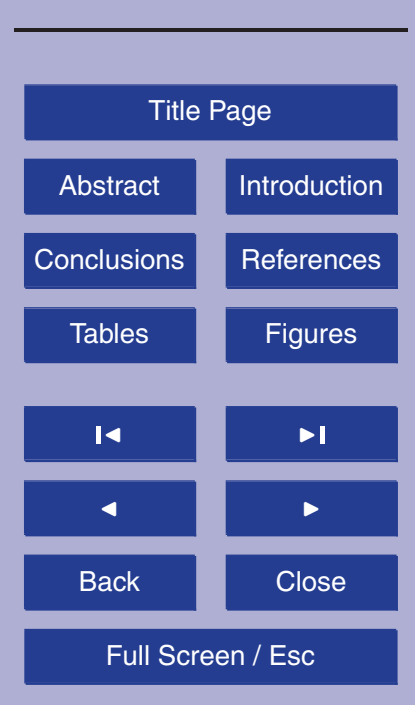

Printer-friendly Version

Interactive Discussion 